\title{
STANDARDIZATION OF Punica granatum EXPLANT AND CALLUS INDUCTION THROUGH MICROPROPAGATION - INDIRECT ORGANOGENESIS
}

\author{
Manasa Satheesh ${ }^{1}$, T.B. Sridharan ${ }^{2}$ \\ ${ }^{1}$ Research scholar, VIT University, Vellore, Tamil Nadu, India \\ ${ }^{2}$ Professor, School of Biosciences and Technology, VIT University, Vellore
}

\begin{abstract}
Pomegranate (Punica granatum L.) and variety name 'Bhagwa' is an ancient, important fruit crop in India and in subtropical countries of the world as it possess various pharmaceutical and therapeutic properties. This is subjected to bacterial blight caused by Xanthomonas axonopodis pv causing a huge loss of about 50-100\% in production. In order to develop a disease resistant pomegranate variety, micro propagation is necessary. The different explants such as leaves, nodes, apical shoot and petals were selected. The explants were passed through surface sterilization process and found that the mortality rate was least with the apical shoots as explants when compared to other explants. Callus Initiation was done with several treatments and the percentage of callus growth was identified using one way ANOVA by which variance was tested using Fischer's F test and LS (Least Squares) means by Duncan's multiple range test which proved that the LS means was higher for all the explants those undergone $M S+$ Sucrose $(30 \mathrm{~g} / \mathrm{l})+$ Adenine sulfate $-40 \mathrm{mg} / \mathrm{l}+6 B A P-5 \mathrm{mg} / \mathrm{l}$ treatment, specifically apical shoot explants showed $92 \%$ callus growth than other explants. The elimination of polyphenol exudation was successful with silver nitrate of 5 $\mathrm{mg} / \mathrm{l}$ which eradicated the browning of the tissues and paved way for the regeneration of the shoots.
\end{abstract}

Key Words: Bhagwa, Micropropagation, Apical shoots, Callus induction, ANOVA, Duncan's test, Polyphenol exudation

\section{INTRODUCTION}

Pomegranate, 'Bhagwa' is a shrub, traditionally propagated by seeds and cuttings resulting in a highly variable progeny. It is being planted widely in various parts of India. Each variety is known for its specific quality giving high yield. 'Bhagwa' pomegranate is the common commercial fruit crop in Maharashtra with bigger fruit size, colored thick skin which is an important reason for its market [1]. This variety is recently getting more demand in market and production because of wide spreading disease bacterial blight caused by Xanthomonas axonopodis [13].

Abundant varieties of Pomegranate such as Mridula, Bhagwa, Ruby, Arakta and Ganesh which are commercially grown crops. The superiority to the fruit yield was shown by Jalore Seedless, G 137 and Ganesh. The Mridula beat all the varieties in its Quality. These varieties excelled in Rajasthan and Punjab [12]. A variety named Kandhari proved the highest Total Soluble Solids (TSS) and Total sugars which is very common in Himachal Pradesh. Pomegranate also possesses Ornamental values [6]. Its main occurrence is as Double Flower, Dwarf or Nana. It is widely cultivated as decorative fruit tree in China

Maximum cultivation of pomegranate is in states of Maharashtra and North Western Karnataka which are very close to the western port of Mumbai for exporting to Gulf and European countries [3]. 'Bhagwa' variety has high acceptance in European market. Till 2012, the export of Pomegranate from India was in tons and the profit was in lakhs [2].

The Pomegranate also possesses various medicinal values. It fights against Breast Cancer, Prostate Cancer, Lowers Cholesterol, Maternal consumption of Pomegranate also cures Brain damage, regular intake of pomegranate juice decreases the risk of heart stroke, gives immunity [11]. Each part of the plant has several health benefits [4]. The rind of the pomegranate when ground into powder and diluted with oil cures anal itching. Such a juicy medicinal tree is being severely attacked by the disease and pests recently attacking a single plant which is easily being spread to the whole crop in few days [5].

This study was intended to standardize the pomegranate explant and to achieve callus induction through indirect organogenesis and the location selected was Hosur near Bangalore which is Bacterial blight affected area. 


\section{MATERIALS AND METHODS}

\subsection{STUDY LOCATION}

The research work was conducted in the Tissue Culture Laboratory Division, Genewin Biotech, Hosur, Tamil Nadu. The Laboratory Center is located $48 \mathrm{~km}$ away from Bangalore at $12.7200^{\circ} \mathrm{N}$ latitude and $77.8200^{\circ} \mathrm{E}$ longitude.

\subsection{GENETIC MATERIALS}

Ten pomegranate healthy plants of 'Bhagwa' were obtained from Vijayalakshmi Nursery, Shimoga, Shimoga district, Karnataka, India for allotting the master code throughout the study and also to establish the mother plant pedigree of 'Bhagwa' Pomegranate. 'Bhagwa' variety is known for the rich coloured fruit which is getting invisible in the market as it is highly prone to Bacterial Blight [7].

\subsection{STOCK PLANTS ESTABLISHMENT}

In the Laboratory Green House, Mother Plant Pedigree had been established from the obtained plants. The sacks were named as PM1, PM2, PM3, PM4, PM5, PM6, PM7, PM8, PM9, and PM10. Pretreatment of obtained plant root zone was done by soaking the cuttings in $0.2 \%$ Streptomycin as bacterial treatment for 2 minutes and rinsed in distilled water; $0.2 \%$ Carbendazim as fungal treatment for 2 minutes and thoroughly rinsed in distilled water. The treated cuttings were planted in a mixture of soil, sand and coco peat $(1: 1: 1)$ [8]. These stock plants were maintained in the greenhouse at an average temperature of $35-40^{\circ} \mathrm{C}$.

\subsection{EXPLANTS PREPARATION}

The explants such as nodes, apical shoot tips, leaves, petals were collected from six months old stock plants grown in the green house. The collected explants were brought to the production laboratory and washed thoroughly in running tap water for $10 \mathrm{~min}$. in order to eliminate the muddy particles from the explants. Nodal explants were excised of about $1-1.5 \mathrm{~cm}$ with the help of secateur. Apical shoot tips, leaves and petals were excised of about $1 \mathrm{~cm}$ with the help of forceps and scalpel [14].

\subsection{EXPLANTS STERILIZATION}

The explants such as nodes, leaves, apical shoot tips and petals were soaked in antifungal and antibacterial solution containing carbendazim $(0.1 \%)$ and streptocycline $(0.1 \%)$ for 30 minutes. The soaked explants were removed and treated with antiseptic solution Dettol or Savlon $(5 \mathrm{ml} / \mathrm{l})$ followed by washing the explants in sterile water. The sterilization is followed by the treatment of detergent, Polysorbate 20 for 15 minutes. The explants were washed with sterile water three times to ensure the complete wash of detergent.

The sterilization is further carried out inside laminar air flow chamber; explants were treated with Ethanol (70\%) for 30 seconds and Mercuric chloride $(0.1 \%)$ for $5 \mathrm{~min}$. The explants were removed and washed with sterile water 3 times to eliminate the toxic effects of Mercuric

The Mortality rate was calculated by

$$
\% \text { Mortality }=\frac{\text { Explants contaminated } \times 100}{\text { Total no of Explants }}
$$

\subsection{EXPLANTS INITIATION}

The sterilized explants such as nodes, leaves, apical shoot tips and petals were inoculated in following MS basal media treatments + Sucrose $3 \%$ with various growth regulator concentrations for callus induction.

T0: Control

T1: Adenine sulfate $-40 \mathrm{mg} / \mathrm{l}+6 \mathrm{BAP}-5 \mathrm{mg} / \mathrm{l}$

T2: Adenine sulfate $-40 \mathrm{mg} / \mathrm{l}+6 \mathrm{BAP}-1 \mathrm{mg} / \mathrm{l}$

T3: Adenine sulfate $-40 \mathrm{mg} / \mathrm{l}+6 \mathrm{BAP}-2 \mathrm{mg} / \mathrm{l}$

T4: Adenine sulfate $-40 \mathrm{mg} / \mathrm{l}+6 \mathrm{BAP}-3 \mathrm{mg} / \mathrm{l}$

T5: Adenine sulfate $-40 \mathrm{mg} / \mathrm{l}+6 \mathrm{BAP}-4 \mathrm{mg} / \mathrm{l}$

T6: $\mathrm{NAA}-1 \mathrm{mg} / \mathrm{l}+6 \mathrm{BAP}-4 \mathrm{mg} / \mathrm{l}$

T7: NAA $-2 \mathrm{mg} / \mathrm{l}+6 \mathrm{BAP}-4 \mathrm{mg} / \mathrm{l}$

T8: $\mathrm{NAA}-3 \mathrm{mg} / \mathrm{l}+6 \mathrm{BAP}-4 \mathrm{mg} / \mathrm{l}$

T9: $\mathrm{NAA}-4 \mathrm{mg} / \mathrm{l}+6 \mathrm{BAP}-4 \mathrm{mg} / \mathrm{l}$

T10: $\mathrm{NAA}-5 \mathrm{mg} / \mathrm{l}+6 \mathrm{BAP}-4 \mathrm{mg} / \mathrm{l}$

The explants such as Nodes and Apical shoots were placed in upright position on each treatment; the Leaves explants were placed abaxial side down on each treatment; each treatment consisted of 40 jars containing two explants in a single jar [9]. The same was repeated for other explants. The inoculated jars were incubated.

\subsubsection{CULTURE CONDITIONS}

For one week, inoculated explants are kept under dark. Then they are subjected under light intensity in the growth room were 10-12 h. photoperiod provided by cool white fluorescent lamps of 1500-3000 lux, temperature of about 25 $\pm 2{ }^{\circ} \mathrm{C}$ and humidity of $35-40 \%$. The observation for the callus induction was recorded after 4-5 weeks.

\subsection{POLYPHENOL EXUDATION}

The most common problem in pomegranate explants is the interference of the polyphenols exudations in growth and becomes toxic for the plant itself [10]. It has the capability to turn the media into dark brown causing slow death of the explants. For the elimination of the polyphenols, the treatment consisted of MS basal media treatments + Sucrose $3 \%+$ Adenine sulfate $-40 \mathrm{mg} / \mathrm{l}+6 \mathrm{BAP}-5 \mathrm{mg} / \mathrm{l}$ with the following polyophenol exudators. 
Table - 1: Trial Treatments for Polyphenol Exudation

\begin{tabular}{|c|c|c|}
\hline TRIALS & $\begin{array}{c}\text { ASCORBIC ACID } \\
+ \text { CITRIC ACID } \\
(\mathrm{mg} / \mathrm{l})\end{array}$ & $\begin{array}{c}\text { SILVER NITRATE } \\
(\mathrm{mg} / \mathrm{l})\end{array}$ \\
\hline 1 & \multirow[t]{5}{*}{$25+12.5$} & 1 \\
\hline 2 & & 2 \\
\hline 3 & & 3 \\
\hline 4 & & 4 \\
\hline 5 & & 5 \\
\hline TRIALS & $\begin{array}{c}\text { Ascorbic Acid + } \\
\text { Citric Acid }(\mathrm{mg} / \mathrm{l})\end{array}$ & PVP (mg/l) \\
\hline 6 & \multirow[t]{5}{*}{$25+12.5$} & 100 \\
\hline 7 & & 200 \\
\hline 8 & & 300 \\
\hline 9 & & 400 \\
\hline 10 & & 500 \\
\hline TRIALS & $\begin{array}{l}\text { Ascorbic Acid + } \\
\text { Citric Acid (mg/l) }\end{array}$ & $\begin{array}{c}\text { ACTIVATED } \\
\text { CHARCOAL (mg/l) }\end{array}$ \\
\hline 11 & \multirow[t]{5}{*}{$25+12.5$} & 100 \\
\hline 12 & & 200 \\
\hline 13 & & 300 \\
\hline 14 & & 400 \\
\hline 15 & & 500 \\
\hline
\end{tabular}

The trial treatments were further performed on the apical bud explants as it responded well with the callus initiation treatment consisted of MS basal media treatments + Sucrose $3 \%$ + Adenine sulfate $-40 \mathrm{mg} / \mathrm{l}+6 \mathrm{BAP}-5 \mathrm{mg} / \mathrm{l}$, and was incubated in the growth room.

\subsubsection{CULTURE}

CONDITIONS

The culture conditions maintained in the growth room were $10-12 \mathrm{~h}$. photoperiod provided by cool white fluorescent lamps of 1500-3000 lux, temperature of about $25 \pm 2{ }^{\circ} \mathrm{C}$ and humidity of $35-40 \%$. The observation for the callus induction was recorded after 4-5 weeks.

\section{RESULTS AND DISCUSSION}

3.1 Effect of Surface Sterilization on Explants

The results of surface sterilization on explants were recorded after a week and the mortality rate of the explants were compared.

Table - 2: Effect of Surface Sterilization on Explants

\begin{tabular}{|c|c|c|c|}
\hline EXPLANTS & $\begin{array}{c}\text { TOTAL NUMER } \\
\text { OF EXPLANTS }\end{array}$ & GOOD & $\begin{array}{c}\text { CONTAMIN } \\
\text { ATION }\end{array}$ \\
\hline Nodes & 50 & 30 & 20 \\
\hline Leaves & 50 & 15 & 35 \\
\hline Apical Shoot & 50 & 48 & 2 \\
\hline Petal & 50 & 18 & 32 \\
\hline
\end{tabular}

Nodes $-40 \%$

Leaves $-70 \%$

Apical shoots $-4 \%$

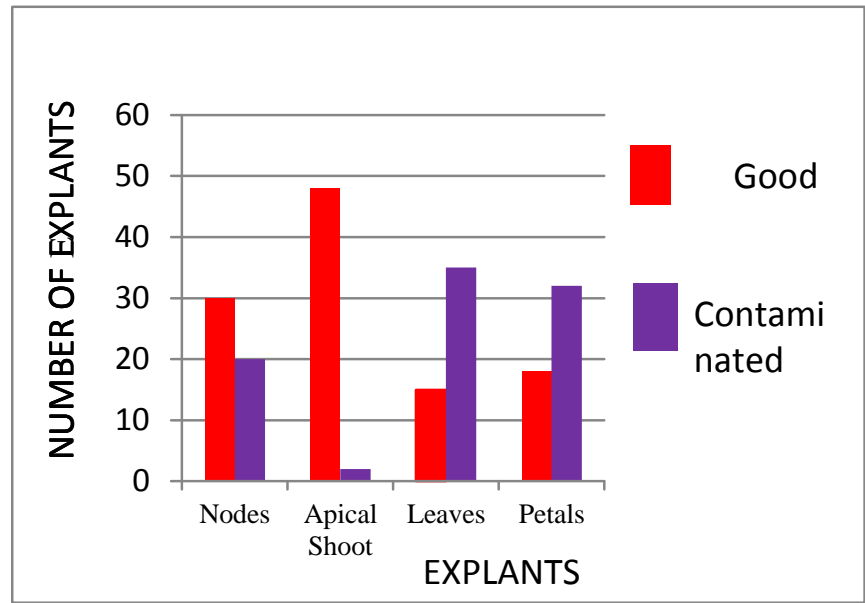

Chart - 1: Effect of Sterilization on Explants

The mortality rate was higher when leaves and petals were used as explants; Sterilization was effective with apical shoots as explants and moderately effective for the nodal explants.

\subsection{CALLUS INDUCTION ON EXPLANTS:}

The incubated explants undergone for analysis by Fischer's test broadening the variance and Least Squares means by Duncan's Multiple Range test which concluded the best Treatment suitable for the explants.

Table - 3: Analysis of variance in nodal explants

\begin{tabular}{|c|c|c|c|c|c|}
\hline Source & DF & $\begin{array}{c}\text { Sum of } \\
\text { squares }\end{array}$ & $\begin{array}{c}\text { Mean } \\
\text { squares }\end{array}$ & F & Pr $>$ F \\
\hline Model & 10 & 35272.294 & 3527.229 & 2635.561 & \\
\cline { 1 - 4 } Error & 98 & 131.156 & 1.338 & & \\
\cline { 1 - 3 } $\begin{array}{c}\text { Corrected } \\
\text { Total }\end{array}$ & 108 & 35403.450 & & & $\begin{array}{c}<0.000 \\
1\end{array}$ \\
\hline
\end{tabular}

Table - 4: Analysis of variance in apical shoot explants

\begin{tabular}{|c|c|c|c|c|c|}
\hline Source & DF & $\begin{array}{c}\text { Sum of } \\
\text { squares }\end{array}$ & $\begin{array}{c}\text { Mean } \\
\text { squares }\end{array}$ & F & Pr $>$ F \\
\hline Model & 10 & 46589.431 & 4658.943 & 2278.073 & \\
\cline { 1 - 5 } Error & 98 & 200.422 & 2.045 & & \\
\cline { 1 - 4 } $\begin{array}{c}\text { Corrected } \\
\text { Total }\end{array}$ & 108 & 46789.853 & & & \multirow{2}{*}{$<0.0001$} \\
\hline
\end{tabular}

Table - 5: Analysis of variance in leaves explants

\begin{tabular}{|c|c|c|c|c|c|}
\hline Source & DF & $\begin{array}{c}\text { Sum of } \\
\text { squares }\end{array}$ & $\begin{array}{c}\text { Mean } \\
\text { squares }\end{array}$ & F & Pr $>$ F \\
\hline Model & 10 & 18596.833 & 1859.683 & 444.956 & \\
\cline { 1 - 5 } Error & 98 & 409.589 & 4.179 & & \\
\cline { 1 - 4 } $\begin{array}{c}\text { Corrected } \\
\text { Total }\end{array}$ & 108 & 19006.422 & & & \multirow{2}{*}{$<0.0001$} \\
\hline
\end{tabular}


Table - 6: Analysis of variance in petal explants

\begin{tabular}{|c|c|c|c|c|c|}
\hline Source & DF & $\begin{array}{c}\text { Sum of } \\
\text { squares }\end{array}$ & $\begin{array}{c}\text { Mean } \\
\text { squares }\end{array}$ & F & Pr $>$ F \\
\hline Model & 10 & 19132.659 & 1913.266 & 68.616 & \\
\cline { 1 - 5 } Error & 98 & 2732.589 & 27.884 & & \\
\cline { 1 - 4 } $\begin{array}{c}\text { Corrected } \\
\text { Total }\end{array}$ & 108 & 21865.248 & & & \multirow{2}{*}{$<0.0001$} \\
\hline
\end{tabular}

The test used here is the Fisher's F test for the analysis of variance using one way ANOVA in all explants. The probability corresponding to the $\mathrm{F}$ value in this case was 0.001 which indicates that there is significant difference in the growth of callus with respect to all treatments compared against control; it means that we would take a $0.1 \%$ risk to conclude that the null hypothesis (no effect of the treatment) is wrong.

Table - 7: Analysis of difference between treatments by Duncan's multiple range test - Nodal Explants

\begin{tabular}{|c|c|c|c|c|c|}
\hline Category & $\begin{array}{c}\text { LS } \\
\text { means }\end{array}$ & $\begin{array}{c}\text { Stand } \\
\text { ard } \\
\text { error }\end{array}$ & $\begin{array}{c}\text { Lower } \\
\text { bound } \\
(95 \%)\end{array}$ & $\begin{array}{c}\text { Upper } \\
\text { bound } \\
(95 \%)\end{array}$ & Groups \\
\hline T0 & 57.222 & 0.386 & 56.457 & 57.987 & D \\
\hline T1 & 80.600 & 0.366 & 79.874 & 81.326 & A \\
\hline T2 & 78.300 & 0.366 & 77.574 & 79.026 & B \\
\hline T3 & 58.700 & 0.366 & 57.974 & 59.426 & C \\
\hline T4 & 40.800 & 0.366 & 40.074 & 41.526 & G \\
\hline T5 & 49.800 & 0.366 & 49.074 & 50.526 & E \\
\hline T6 & 44.300 & 0.366 & 43.574 & 45.026 & F \\
\hline T7 & 29.200 & 0.366 & 28.474 & 29.926 & I \\
\hline T8 & 31.400 & 0.366 & 30.674 & 32.126 & H \\
\hline T9 & 31.700 & 0.366 & 30.974 & 32.426 & H \\
\hline T10 & 28.200 & 0.366 & 27.474 & 28.926 & I \\
\hline
\end{tabular}

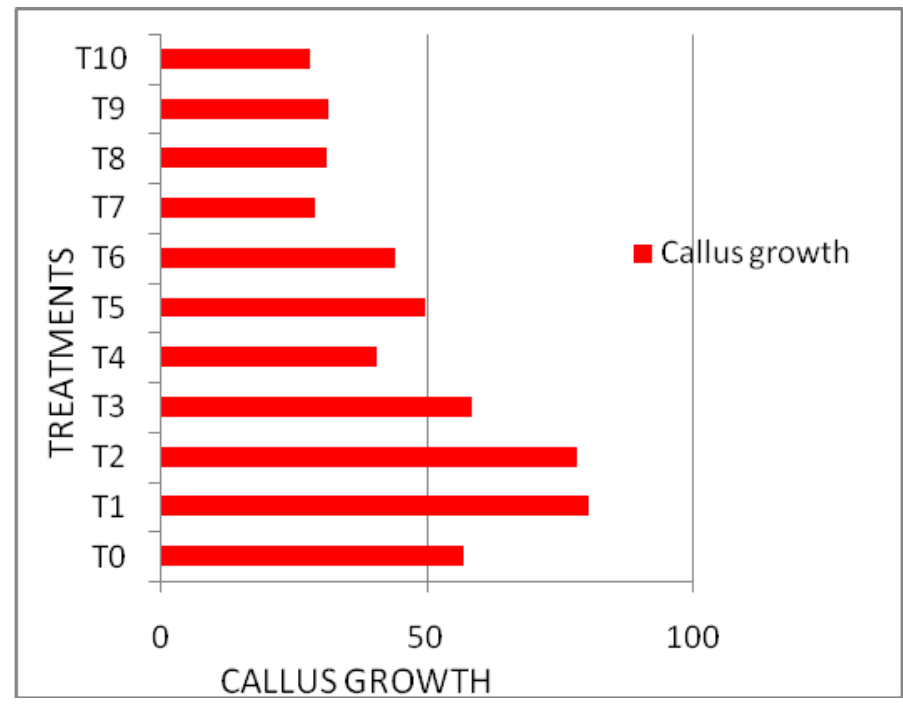

Chart - 2: Efficiency of Treatments in Nodal Explant
Table 8: Analysis of difference between treatments by Duncan's multiple range test - Apical shoot Explants

\begin{tabular}{|l|c|c|c|c|c|}
\hline Category & $\begin{array}{c}\text { LS } \\
\text { means }\end{array}$ & $\begin{array}{c}\text { Standa } \\
\text { rd } \\
\text { error }\end{array}$ & $\begin{array}{c}\text { Lower } \\
\text { bound } \\
(95 \%)\end{array}$ & $\begin{array}{c}\text { Upper } \\
\text { bound } \\
(95 \%)\end{array}$ & Groups \\
\hline T0 & 57.556 & 0.477 & 56.610 & 58.502 & D \\
\hline T1 & 92.100 & 0.452 & 91.203 & 92.997 & A \\
\hline T2 & 80.600 & 0.452 & 79.703 & 81.497 & B \\
\hline T3 & 62.100 & 0.452 & 61.203 & 62.997 & C \\
\hline T4 & 50.600 & 0.452 & 49.703 & 51.497 & E \\
\hline T5 & 48.300 & 0.452 & 47.403 & 49.197 & F \\
\hline T6 & 41.100 & 0.452 & 40.203 & 41.997 & G \\
\hline T7 & 30.700 & 0.452 & 29.803 & 31.597 & H \\
\hline T8 & 31.000 & 0.452 & 30.103 & 31.897 & H \\
\hline T9 & 31.400 & 0.452 & 30.503 & 32.297 & H \\
\hline T10 & 25.700 & 0.452 & 24.803 & 26.597 & I \\
\hline
\end{tabular}

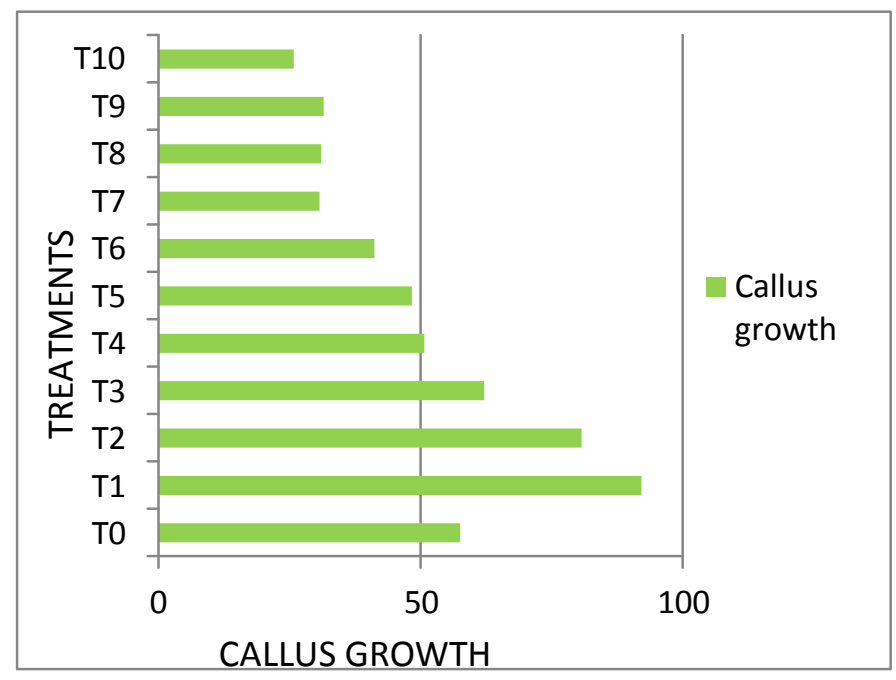

Chart - 3: Efficiency of Treatments in Apical Shoot Explant

Table 9: Analysis of difference between treatments by Duncan's multiple range test - Leaves Explants

\begin{tabular}{|l|c|c|c|c|c|}
\hline Category & $\begin{array}{c}\text { LS } \\
\text { means }\end{array}$ & $\begin{array}{c}\text { Standa } \\
\text { rd } \\
\text { error }\end{array}$ & $\begin{array}{c}\text { Lower } \\
\text { bound } \\
(95 \%)\end{array}$ & $\begin{array}{c}\text { Upper } \\
\text { bound } \\
(95 \%)\end{array}$ & Groups \\
\hline T0 & 33.889 & 0.681 & 32.537 & 35.241 & F \\
\hline T1 & 70.700 & 0.646 & 69.417 & 71.983 & A \\
\hline T2 & 56.800 & 0.646 & 55.517 & 58.083 & B \\
\hline T3 & 48.900 & 0.646 & 47.617 & 50.183 & C \\
\hline T4 & 40.600 & 0.646 & 39.317 & 41.883 & D \\
\hline T5 & 38.300 & 0.646 & 37.017 & 39.583 & E \\
\hline T6 & 41.100 & 0.646 & 39.817 & 42.383 & D \\
\hline T7 & 29.700 & 0.646 & 28.417 & 30.983 & G \\
\hline T8 & 31.000 & 0.646 & 29.717 & 32.283 & G \\
\hline T9 & 30.300 & 0.646 & 29.017 & 31.583 & G \\
\hline T10 & 24.500 & 0.646 & 23.217 & 25.783 & H \\
\hline
\end{tabular}




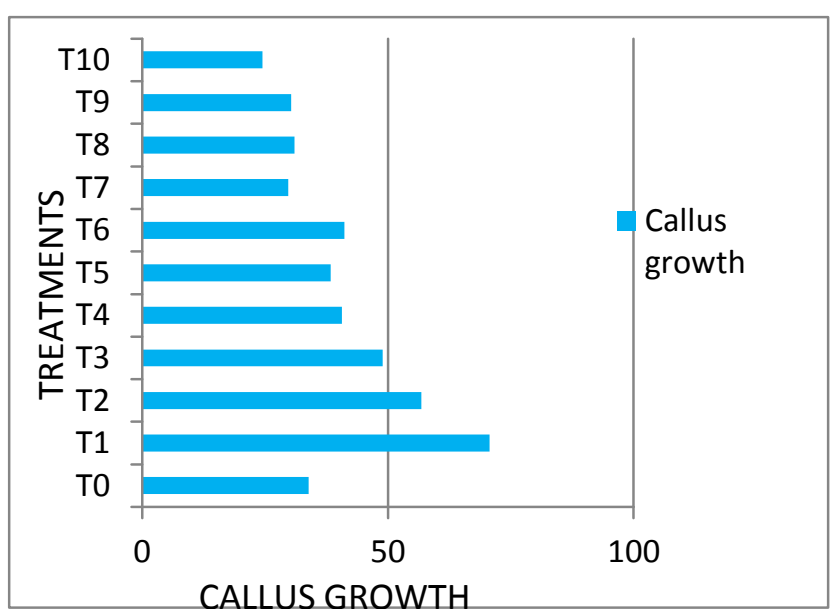

Chart - 4: Efficiency of Treatments in Leaves Explant

Table 10: Analysis of difference between treatments by Duncan's multiple range test - Petal Explants

\begin{tabular}{|l|c|c|c|c|c|c|}
\hline Category & $\begin{array}{c}\text { LS } \\
\text { means }\end{array}$ & $\begin{array}{c}\text { Standa } \\
\text { rd } \\
\text { error }\end{array}$ & $\begin{array}{c}\text { Lower } \\
\text { bound } \\
(95 \%)\end{array}$ & $\begin{array}{c}\text { Upper } \\
\text { bound } \\
(95 \%)\end{array}$ & Groups \\
\hline T0 & 24.111 & 1.760 & 20.618 & 27.604 & G & H \\
\hline T1 & 70.100 & 1.670 & 66.786 & 73.414 & \multicolumn{2}{|c|}{ A } \\
\hline T2 & 35.200 & 1.670 & 31.886 & 38.514 & D & E \\
\hline T3 & 32.000 & 1.670 & 28.686 & 35.314 & E & F \\
\hline T4 & 40.600 & 1.670 & 37.286 & 43.914 & \multicolumn{2}{|c|}{ C } \\
\hline T5 & 46.300 & 1.670 & 42.986 & 49.614 & \multicolumn{2}{|c|}{ B } \\
\hline T6 & 39.200 & 1.670 & 35.886 & 42.514 & C & D \\
\hline T7 & 28.700 & 1.670 & 25.386 & 32.014 & F & G \\
\hline T8 & 27.300 & 1.670 & 23.986 & 30.614 & F & G \\
\hline T9 & 24.000 & 1.670 & 20.686 & 27.314 & G & H \\
\hline T10 & 21.900 & 1.670 & 18.586 & 25.214 & \multicolumn{2}{|c|}{ H } \\
\hline
\end{tabular}

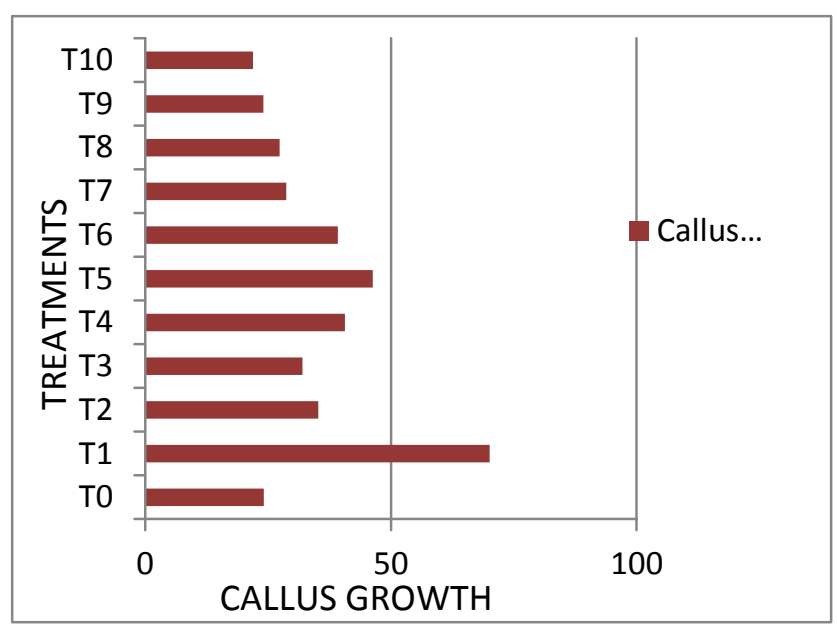

Chart - 5: Efficiency of Treatments in Petal Explant
The Duncan's Multiple Range test resulted in evaluating the LS means of higher percentage with T1 treatment for all explants. The performance was higher with Apical Shoot explant which resulted in $92 \%$ of callus growth other than all explants which had grown to $80 \%$, $70 \%$ and $70 \%$ for Nodes, Leaves and Petals respectively. Further, the Polyphenol Exudation was continued with Apical Shoot.

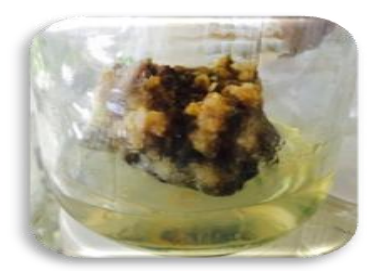

a

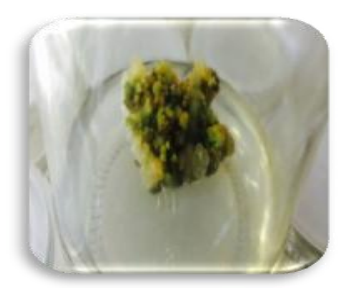

b
Fig - 1: Callus Growth
a. Pale Callus
b. Healthy Callus

The figures represent the growth of callus in respective treatments which showed pale callus growth in all the treatments including control while the healthy green callus was healthy as a result of $\mathrm{T} 1$ treatment.

\subsection{EFFECT OF POLYPHENOL EXUDATION:}

\subsubsection{Determination of callus growth after the elimination of polyphenols}

Table - 11: Polyphenol exudation using silver nitrate - 1 - 5 $\mathrm{mg} / \mathrm{l}$ :

\begin{tabular}{|c|c|c|c|c|c|}
\hline \multirow{2}{*}{ EXPLANTS } & \multicolumn{5}{|c|}{ POLYPHENOL EXUDATED } \\
\cline { 2 - 6 } & $1 \mathrm{mg}$ & $2 \mathrm{mg}$ & $3 \mathrm{mg}$ & $4 \mathrm{mg}$ & $5 \mathrm{mg}$ \\
\hline Nodes & ++++ & +++ & +++ & +++ & ++ \\
\hline Leaves & ++++ & +++ & +++ & ++ & ++ \\
\hline Petal & ++++ & +++ & +++ & +++ & ++ \\
\hline Apical shoot & +++ & +++ & ++ & ++ & - \\
\hline
\end{tabular}

Table - 12: Polyphenol exudation using PVP $-100-500 \mathrm{mg} / \mathrm{l}$

\begin{tabular}{|c|c|c|c|c|c|}
\hline \multirow{2}{*}{ EXPLANTS } & \multicolumn{5}{|c|}{ POLYPHENOL EXUDATED } \\
\cline { 2 - 6 } & $100 \mathrm{mg}$ & $\begin{array}{c}200 \\
\mathrm{mg}\end{array}$ & $\begin{array}{c}300 \\
\mathrm{mg}\end{array}$ & $\begin{array}{c}400 \\
\mathrm{mg}\end{array}$ & $\begin{array}{c}500 \\
\mathrm{mg}\end{array}$ \\
\hline Nodes & ++++ & +++ & +++ & ++ & + \\
\hline Leaves & +++ & +++ & +++ & +++ & +++ \\
\hline Petal & +++ & +++ & +++ & +++ & ++ \\
\hline Apical shoot & +++ & +++ & +++ & +++ & ++ \\
\hline
\end{tabular}


Table - 13: Polyphenol exudation using Activated charcoal - $100-500 \mathrm{mg} / \mathrm{l}$

\begin{tabular}{|c|c|c|c|c|c|}
\hline \multirow{2}{*}{ EXPLANTS } & \multicolumn{5}{|c|}{ POLYPHENOL EXUDATED } \\
\cline { 2 - 6 } & $100 \mathrm{mg}$ & $\begin{array}{c}200 \\
\mathrm{mg}\end{array}$ & $\begin{array}{c}300 \\
\mathrm{mg}\end{array}$ & $\begin{array}{c}400 \\
\mathrm{mg}\end{array}$ & $\begin{array}{c}500 \\
\mathrm{mg}\end{array}$ \\
\hline Nodes & ++++ & +++ & +++ & ++ & ++ \\
\hline Leaves & +++ & +++ & +++ & +++ & ++ \\
\hline Petal & +++ & +++ & +++ & +++ & +++ \\
\hline Apical shoot & +++ & +++ & ++ & ++ & + \\
\hline
\end{tabular}

Note: ++++ Very high; +++ High; ++ Moderately high ; + Low; - Nil

' ++++ ' here represents that the callus induced very high polyphenol exudation; ' +++ ' indicates that the callus induced high polyphenol exudation; ' ++ ' indicates the moderately high polyphenol exudation; ' + ' indicates low polyphenol exudation in callus; '-' indicates nil polyphenol exudation which was observed with Trial 5 that helped in the regeneration of callus into shoots. The other exudators were not effective for the elimination of polyphenols in 'Bhagwa' Pomegranate variety.

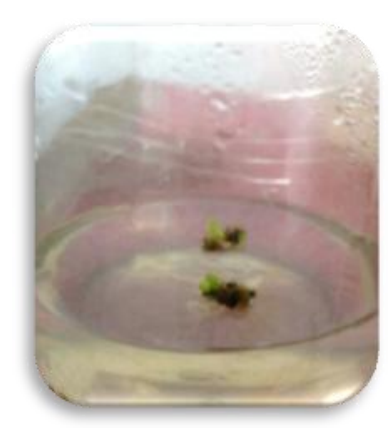

a

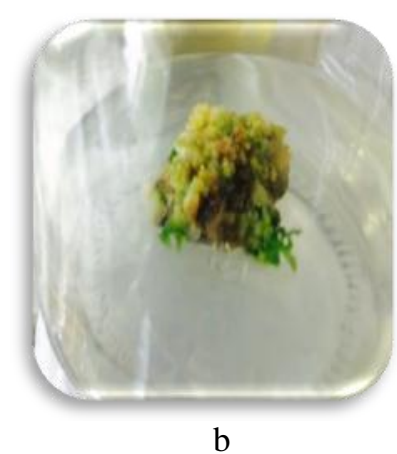

\begin{abstract}
b. After
a. Before
\end{abstract}

Fig - 2: Polyphenol Exudation

\section{CONCLUSION}

Apical shoots were the best part which has the ability to regenerate the callus into shoots. The initiation treatment for callus induction was proved in apical shoots explant in T1 treatment with green healthy callus when compared to the $\mathrm{T} 2$ and $\mathrm{T} 3$ treatments which produced the dull callus. The significance effects of the callus growth were calculated using one way ANOVA. Duncan's multiple range test proved the best treatment for the selected explants which showed 92\% growth in apical Shoots; $80 \%$ growth in nodes, $70 \%$ growth in leaves and petals. The polyphenols exudation was eliminated by incorporating Silver nitrate of $5 \mathrm{mg} / \mathrm{l}$ in the MS + Sucrose $(30 \mathrm{~g} / \mathrm{l})+$ Adenine sulfate $40 \mathrm{mg} / \mathrm{l}+6 \mathrm{BAP}-5 \mathrm{mg} / \mathrm{l}$. Indirect Organogenesis was achieved from the 'Bhagwa' pomegranate explants which have the ability to produce the disease free plants. 'Bhagwa' Pomegranate variety is very common among all other varieties which is recently known for Bacterial blight attack [15]. In order to bring back the Rich 'Bhagwa' pomegranate into the market. Micropropagation is the only effective way to produce disease free plants.

\section{ACKNOWLEDGEMENTS:}

My sincere thanks to my guide Dr. T. B. Sridharan, VIT University, Vellore who guided me technically in carrying out my Research work successfully.

\section{REFERENCES}

[1] AlirezaBonyanpour and MortezaKhosh-Khui, "In vitro Plant Regeneration from callus in semi dwarf cultivar of Punica granatumL. 'Nana'”, Journal of Applied Biological Sciences 7 (1), pp. 47-51, 2013.

[2] Dan MacLean, Karina Martino, HaraldScherm, Dan Horton, "Pomegranate Production, Agricultural and Environmental Sciences", pp. $1-12$.

[3] F. Soukhak, A. Khalighi, S. A. Ghaemmaghami, "Study of Direct Adventitious Shoot Regeneration in Pomegranate (Punicagranatumcv. alasSaveh ) through Cotyledonary Explants", International Journal of Agricultural Science and Research, 2 (3), pp. 19 - 26, 2011.

[4] Jaime A. Teixeira da Silva, Tikam Singh Rana, DigantaNarzary, NidhiVerma, DeodasTarachanMeshram, Shirish A. Ranade, "Pomegranate biology and biotechnology: A review", ScientiaHorticulturae, 160, pp. $85-107,2013$.

[5] Jaya Singh, Saurabh Gupta, ParasKhoshe, "In vitro Regeneration of Pomegranate (PunicagranatumL.) from Nodal Explant", International Journal Of Advances InPharmacy, Biology And Chemistry, 3(3), 2014.

[6] R. Kumar, M.R. ShamaraoJahagirdar, S.T. Yenjerappa and H.B. Patil, "Epidemiology and management of bacterial blight of pomegranate caused by Xanthomonas axonopodis pv. Punicae”. Acta Horticulture. (ISHS), 818, pp. 291-296, 2009.

[7] R. Lokesh, Erayya, K.M. Kumaranag, N. Chandrashekar and A.N.A. Khan, "In vivo Efficacy of some Antibiotics against Bacterial Blight of Pomegranatecaused by Xanthomonas axonopodis pv. Punicae”, International Research Journal of Biological Sciences, 3(1), pp. 31 - 35, 2014.

[8] Mohamed Nasr. Helaly, Hanan El-Hosieny, Tobias M. Ntuli, Ibtisam Alsudays, Samar Abdelaziz Omar, Nabil I Elsheery, "In vitro studies on regeneration and transformation of some pomegranate genotypes", Australian Journal of Crop Science, 8(2), pp. 307-316, 2014.

[9] Pushpraj Singh, R.M. Patel, SmitaKadam, "In vitro mass multiplication of pomegranate from cotyledonary nodal explants cv. Ganesh", 12 (20), 2863 - 2868, 2013.

[10] Raj Deepika Chauhan and Kamlesh Kanwar, "Biotechnological advances in pomegranate (Punicagranatum L.)", In Vitro Cell Developmental Biology -Plant, 48, pp. 579-594, 2012.

[11] Sandip Khanuchiya, Farzin M. Parabia, Mansi Patel, Vishal Patel, Kuldeep Patel and Bharat Gami, 'Effect of pseudomonas fluorescence, $P$. aeruginosa and Bacillus subtillus as biocontrol agent for crop protection", 2012.

[12] Soumendra K. Naik, SitakantaPattnaik, Pradeep K. Chand, "High frequency axillary shoot proliferation and plant regeneration from cotyledonary nodes of pomegranate 
(Punicagranatum L.)", Scientia Horticulturae, 85, pp. 261 270, 2000.

[13] Surinder Kumar, Jitender Kumar Kanwar, "Regeneration ability of petiole, leaf and petal explants in gerbera cut flower cultures in vitro", Folia Horticulturae, 18(2), pp. $57-64,2006$.

[14] S.R. Vasane and J.L. Patil, "Multiplying benefits with acclimatization practices (gacp) in tissue culture propagated mrudula pomegranate", ActaHorticlture (ISHS). 988, pp.7784, 2013.

[15] Vijay M. Patil, G. A. Dhande, Dipak M. Thigale and J. C. Rajput, "Micropropagation of pomegranate (Punica granatumL.) 'Bhagava' cultivar from nodal explants", African Journal of Biotechnology, 10(79), pp. 18130-18136, 2011.

\section{BIOGRAPHIES}

\section{Manasa Satheesh}

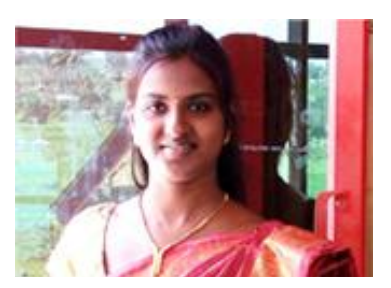

Date \& Place of birth: 23-12-1987, Shimoga.

Degree earned: Under graduate in Bachelor of technology (Biotechnology) from Sathyabama University, Chennai, Tamil Nadu in the year 2005 - 2009. Post-graduation in Master of technology (Biotechnology) from Sathyabama University, Chennai in the year 2010 to 2012.

Current Position: Research Scholar in VIT University, Vellore

Work Experience: Director of Genewin Biotech (Producers of Quality Tissue Culture plants), Hosur from 2007 till date.

\section{Previous publications:}

1. Caral Dinesh R, Vinay P, Manasa P, Vinoth kumar D and Ramesh Babu N G, Comparative study of oyster mushroom (Pleurotus ostreatus) cultivation by physical and chemical method of sterilization using two different substrates, International journal of Scientific \& Engineering Research, Volume 4,iue 9,pp 898-902, September 2013.

2. E. Anitha, V. Praveena, N.G, Ramesh Babu and P. Manasa, Enumeration of Foliar Fertilizer Efficiency in India's top commercial crop - TEA, International Journal of Innovatie Research in Science, Engineering and Technology, vol 2, issue 12 December 2013, ISSN:23198753,PP 8038-8046.

3. M. Malathi and M.Vanathi, P. Manasa, C. Saravanakumar, N. G. Ramesh Babu, , Analyzing Composts from Different Sources and Checking the Availability of Nutrients, International Journal of Engineering Research \& Technology, Vol. 2 Issue 12, December 2013. 4. S. Sivabalan, P. Ramkumar, P. Manasa Satheesh, S. Muyeed Ahmed, Detection of Albino in Micropropagated Shoots of Bambusa Balcooa Roxb, Using PCR Based
Techniques, International Journal of Engineering Research \& Technology, Vol. 3 Issue 3, March - 2014.

5. S. Dhanapal, D. Sathish Sekar, P. Manasa, Enhancement of Antioxidant Potential in Musa Accuminata using Humic Acid, International Journal of Agriculture Innovations and Research, Volume 2, Issue 4, ISSN (Online) 2319-1473. 6. S. Dhanapal, D. Sathish Sekar \& P. Manasa Satheesh, Efficiency of RAPD, SSR and ISSR markers in evaluating the Genetic Fidelity for micropropogated Musa accuminata plant exposed to Coal extracted Humic acid and commercially available products, International Journal of Agricultural Science and Research (IJASR), ISSN(P): 22500057; ISSN(E): 2321-0087, Vol. 4, Issue 4, Aug 2014, 7786.

7. G. Krithika, P. Manasa Satheesh, Mass Production of Microalgae Using Waste Water as Supplement and Extraction of Bio Oil by Transesterification, International Journal of Innovative Research in Science, Engineering and Technology, Vol. 3, Issue 9, September 2014.

\section{Dr.T.B.Sridharan

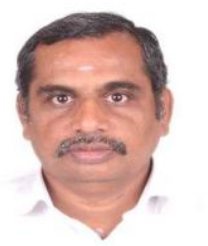

Degree earned: Ph D.,

Work Experience: Professor, School of Biosciences and Technology, VIT University

Publications

1. T.B.Sridharan, Shri Praksh, R.S. Chauhan, K.M. Rao, Kusum Singh and R. Naresh singh - Sensilla on the palps and legs of the adult ticks Argas Persicus Oken(Ixodoidea: argasidae and their projhections in to the central nervous system. Int. J. Insect Morphol. And Embryol. USA. 27(4): 273-289.1998

2. Sridharan, T. B. Mendki, M. J. Prakash, S. Agarwal, O. P. Chauhan, R. S. (2002). Morphology and distribution of sensilla in palp and leg appendages of larva and nymph of Argas persicus Oken (Acarina: Argasidae) Entomon. 27(4); 393-402.

3. Sridharan.T.B. and G. Jayaraman (2007) Phytoremediation of Chromium - a Green clean technology. Advanced Biotech. 6(2): 9-15.

4. Ilamathi, M., Mahalakshmi,T. and T.B. Sridharan (2008). Effect of chromium in microbial growth. Asian Journal of Micro. Biotech \& Environmental sciences. 10(4): 759-764.

5. Ilamathi, M., Mahalakshmi, T., Venkat Kumar, S., Ramesh Pathy, M., Jayaraman, G. and T. B. Sridharan (2009). Chromium Tolerance Studies on E. coli and S. cerevisiae. VIT Journal of Engineering, Management and Sciences. 1(1): 146- 157.

6. Mahalakshmi, T. Ilamathi, M, Siva, R. and T. B. Sridharan. (2010) Effect of Nickel tolerance in E. coli 
and S. cereviseae. Industrial Pollution Control Research. 26 (2): 5-13.

7. Sridharan, T. B., Soham Shah, Leena Jamal, Venkat Kumar, S. Ramesh Pathy M. Siva, R. and G Jayaraman. (2010) Determination in the change in the efficiency of various antibiotics before and after expiry. Journal of Pharmacy Research. 3(5): 1068-1073

8. T. B. Sridharan. (2011). Genetically Modified Crops: Their Effect on Agriculture and Food Security. Environ. We Int. J. Sci. Tech. 6: 49-69.

9. Mythili, S., A.Sathiavelu and T. B. Sridharan (2011). Evaluation of antioxidant activity of Cassytha filiformis. International Journal of Applied Biology and Pharmaceutical Technology. 2(2): 380-385.

10. Mythili, S., A. Sathiavelu, and T. B. Sridharan (2011). Antimicrobial activity of selected Indian folk medicinal plants. Journal of Pharmacy Research 4(6): 1894-1898

11. Mythili, S. Gajalakshmi, A. Sathiavelu, and T. B. Sridharan (2011). Pharmacological Activities of Cassytha Filiformis: A Review. Asian J. Plant Sci. Res., 1 (1):77-83

12. Neelam Dwivedi, Arunagirinathan M. A, P. Giridharan, T. B. Sridharan, Somesh Sharma and Jayesh Bellare. (2011). Cochleate Microstructures for Insulin Delivery, Minnesota Microscopy Society, University of Minnesota, Minneapolis, USA, January 27. (Won IPAD for Best Poster Presentation)

13. Vickram, A. S., Ramesh Pathy, M., Sridharan.T. B. and J Srinivasan (2011). Optimization Of Semen Preparation Techniques Based On Rpm For Assisted Reproductive Technology Journal of Pharmacy research 4(8): 2627-2632.

14. T. B. Sridharan, Ani Jacob Mathew, Ankit Kapoor, Ankit Srivastava, Gaurav Shrivastava, Ipsita Pujari, Ishani Das, Karthikeyan M, Neilli Chotani, Pritha Ghosh, A S Vickram, Devi Rajeswari, Ramesh Pathy, Venkat Kumar and G Jayaraman. (2011). Molecular level study to understand the difference in response of Escherichia coli against expired/non-expired drugs. Journal of Pharmacy Research 4(11);4157-4160

15. T. B. Sridharan, Radha S Sasvihalli, N Prathyusha Devi, Siddeswari S, SalmaV, Vickram A S, Devi Rajeswari, Ramesh Pathy M, Venkat Kumar S. (2012). Study on Efficacy of Expired and Active Forms of Various Antibiotics on Saccharomyces cerevisiae. Research in Biotechnology, 3(1): 29-35, 2012

16. Devi Rajeswari V, G. Jayaraman, M. Rameshpathy and T B Sridharan (2012) Production And Characterization Of Extracellular Protease From Halotolerant Bacterium Virgibacillus dokdonesis VITP14. Res. J. Biotech 7 (2): 38-43

17. Rameshpathy, M., Jayaraman, G., Devi Rajeswari, V., Vickram, A. S., Sridharan, T, B. (2012). Emergence of Class A $\beta$-lactamase producing Multiple Antibiotics Resistant Halomonas hydrothermalis strain VITP09, isolated from Kumta coast. International Journal of Pharmacy and Pharmaceutical sciences 4(3): 566-568

18. Devi Rajeswari V. and Sridharan T. B. (2012). Purification and Characterization of Extracellular Protease from Halotolerant Bacterium Virgibacillus
VITP14 Research Journal Of Biochemistry. 7(3): 123132.

19. Vickram A.S, Ramesh Pathy M, Sridharan T.B. (2012). Effect Of Various Biomolecules For Normal Functioning Of Human Sperm For Fertilization: A Review. International Journal Of Pharmacy And Pharmaceutical Sciences 4(4); 18 - 24.

20. Devi Rajeswari V, G. Jayaraman, T. B. Sridharan (2012). Application studies of the halotolerant protease from a newly isolated Virgibacillus dokdonensis VIT P14 Research in Biotechnology, 3(6): 59-66.

21. Poonam R. Inamdar, Jyotsna Hazarika, T. B. Sridharan and A. Sheela (2012). Synthesis And Dna Binding Study Of Zinc (Ii) Co-Ordination Complexes. Advanced Materials Research 584: 401-405

22. Vickram Sundaram, MS Srinivas, Kamini A Rao, M Ramesh Pathy, T.B. Sridharan (2012) A Comparative Study of Distribution of Protein and Cholesterol in Various Fractions of Human Semen from Infertile and Fertile Subjects. Int $J$ Infertility Fetal Med 2012;3(3):78-82. (Pubmed Citation)

23. Vickram A. S. \& Raja Das \& Srinivas M. S. Kamini A. Rao \& Jayaraman G., Sridharan T. B. (2013). Prediction of $\mathrm{Zn}$ concentration in human seminal plasma of Normospermia samples by Artificial Neural Networks (ANN). J Assist Reprod Genet (2013) 30:453-459 (Impact Factor : 2.3)

24. Vickram Sundaram, Muthugadhalli Srinivas, Jayaraman Gurunathan, Kamini Rao, Ramesh Pathy Maniyan, Sridharan Balasundaram, (2013), Influence Of Trace Elements And Their Correlation With Semen Quality In Fertile And Infertile Subjects. Turk J Med Sci (2013) 43 (6): 1000-1007 (Impact Factor : 0.6)

25. Modi Mega, Unnikrishnan Unnama, Manian Ramesh pathy., Kulanthivelu Karikalan, Sundaram Vickram, S Venkat Kumar, Balasundaram Sridharan (2013). Formulation of nano-encapsulated poly-herbal ointment for anti inflammation Der Pharmacia Letter 5(6); 164170 .

26. Vickram, A.S., V. Devi Rajeswari, M. Srinivas, G.Jayaraman, RA Kamini, M. Ramesh Pathy, S. Venkat Kumar and T. B. Sridharan (2014). Correlation Studies On Human Seminal Plasma Proteins and Their Relation with Semen Freezablity. Asian J. Biochem 9 (1); 41-48 (Impact Factor : 0.2)

27. Nalini Eswaran, S Karthikeyan., T. B. Sridharan and K M Gothandam (2014) Identification and analysis of salt tolerant property of AHL lactonase $\left(\mathrm{Aii}_{\mathrm{TSAWB}}\right)$ of Bacillus Species. J. Basic Microbiol 54: 1-12

Accepted

28. Vickram, A.S., Ramesh Pathy, M Devi Rajeswari, V. and T B Sridharan. (2013). Analysis of seminal plasma proteins of south Indian Jercy and Hybrid bulls and their correlation with semen quality Asian Journal of animal and verternary advances (Mss no. 43455AJAVA-AJ) (Accepted)

29. Vickram A.S, Jayaraman G, Ramesh Pathy M,Srinivas M,Kamini Rao, Sridharan T. B. Biochemical Analysis Of Fructose Concentration And A-Glucosidase Activity In Human Seminal Plasma Of Various Infertile And 
Fertile Categories With Reference To Semen Quality. Journal Of Medical Biochemistry (Under Revision, Impact Factor (1)

30. Vickram Sundaram, Raja Das, Srinivas M.S, Kamini A Rao, Jayaraman G, Venkat Kumar S, Sridharan T.B. Evaluation Of Zn Concentration By Atomic Absorption Spectroscopy In Human Seminal Plasma Of Asthenospermic Patients And Prediction With Artificial Neural Networks. Asian Biomedicine (Under Review, Impact 0.6)

\section{Communicated}

31. Parameswari R, Ramesh Pathy M, Vickram A. S. and T. B. Sridharan*, Smoking and Male Infertility: A Review 